\title{
Prevalence, relative risk factors and hemato-biochemical changes associated with equine trypanosomosis in eastern plane zone of Uttar Pradesh
}

\author{
V. K. Pal ${ }^{1 *}$, A. Singh ${ }^{1}$, H. K. Singh ${ }^{1}$ and K. Sethi ${ }^{2}$ \\ ${ }^{1}$ Department of Veterinary Parasitology, College of Veterinary Science and Animal Husbandry, \\ Acharya Narendra Deva University, Kumarganj, Ayodhya- 224 229, Uttar Pradesh, India; ${ }^{2}$ ICAR- \\ National Research Centre on Equines, Sirsa Road, Hisar-125 001, Haryana, India
}

\begin{abstract}
Equine trypanosomosis has negative impacts on health and working efficiency of equines in different areas of the world including India. A cross sectional survey was conducted in thirteen districts of eastern plane zone of Uttar Pradesh, India during August to November, 2020 to evaluate the molecular and serological prevalence, relative risk factors and hemato-biochemical alterations of equine trypanosomosis. A total of 285 equine blood samples of both sex and different age groups were collected for the study. The overall prevalence of $T$. evansi infection in equines was 15.08 percent by Invariable surface glycoprotein (ISG) PCR and 19.29 percent by indirect-ELISA. The relative risk factors among different animals associated with PCR and ELISA techniques indicated that donkeys/mules were 27.08 and 34.65 times more prone to infection than horses. The young animals as well as parasite infected animals were also more susceptible to this infection than adult and parasite naive animals. Significant alterations in hemato-biochemical parameters (viz. Hb, PCV, TEC, MCV, MCHC, absolute lymphocyte count, TSP, albumin, globulin, serum glucose, serum enzymes, blood urea, creatinine and uric acid) were observed in infected animals as compared to infection free control.
\end{abstract}

Key words: Eastern plane zone, Equine trypanosomosis, Indirect-ELISA, Relative risk factors, T. evansi

\section{INTRODUCTION}

The causative agent of surra, Trypanosoma evansi, is transmitted mechanically by hematophagus flies such as Tabanus (horse flies) and Stomoxys (stable flies). In India, it is found as an endemic, mostly in north and north-western region (Yadav et al., 2012). The overall serological prevalence of animal trypanosomosis is $11.36 \%$ in North and North-western states of India; in which maximum was recorded (19.69\%) in Uttar Pradesh state (Kumar et al., 2013). Animal trypanosomosis caused several sporadic outbreaks of equine in different parts of India (Yadav et al., 2012). The clinical signs of equine trypanosomosis are intermittent fever, severe weight loss, progressive weakness, anaemia, hemoglobinuria, petechial hemorrage of mucous membranes, ventral and genital oedema, urticarial plaques, conjunctivitis and keratitis and sever neurological signs. The typical neurological signs of infection with
T. evansi are ataxia and paralysis of the hind quarter and lips usually precede that results death of animal (Aregawi et al., 2019). The severity of clinical signs of the disease depends upon the parasite strain, concurrent infection, stress, environmental factors and the immunological status of the host. Chronic form is most common in equine that persists for several months up to 2 years and is likely to present in association with secondary infection due to immune-suppression caused by $T$. evansi infection (Ahmed, 2008). Thus, surra has significant socio-economic importance and causes severe economic losses to the poor farmers in terms of poor production, sometimes abortion and death without treatment. The total annual loss caused by surra has been estimated to be INR 44740 million in India (Kumar et al., 2017).

As per $20^{\text {th }}$ livestock census, the equine population was found to be highest in Uttar Pradesh among the equine rearing states in 
India (Department of Animal Husbandry, Dairying and Fisheries, Ministry of Agriculture, GoI). Generally, marginal people of this state rear equines for earning their livelihoods and use them in transport of goods, construction work, brick kilns, tourist and pilgrim places and marriage-ceremony etc. without following a definite system of management and husbandry practices. In Eastern Uttar Pradesh, detailed and systematic studies have not been conducted on equine trypanosomosis. Hence, the present study was carried out to know the prevalence of $T$. evansi and relative risk factors along with estimation of hemato-biochemical alteration associated with equine trypanosomosis in eastern plane zone of Uttar Pradesh.

\section{MATERIALS AND METHODS Ethical statement}

An Institutional Animal Ethics Committee (IAEC) of Acharya Narendra Dev University of Agriculture and Technology, Kumarganj, Ayodhya, Uttar Pradesh granted an approval (IAEC/CVSc/2/P-32/2020/26) for conducting the present study.

\section{Study area}

The eastern Uttar Pradesh covers an area of 85,804 square kilometer and situated between $23^{\circ} 50^{\prime} \mathrm{N}$ to $28^{\circ} 25^{\prime} \mathrm{N}$ and $81^{\circ} 10^{\prime} \mathrm{E}$ to $84^{\circ} 40^{\prime} \mathrm{E}$. The present study was conducted in thirteen districts of eastern plain zone of Uttar Pradesh (UP), India. The climate is defined as moist sub humid, temperature ranges from $5.7^{\circ} \mathrm{C}$ to $41.4^{\circ} \mathrm{C}$ and average rainfall is $803 \mathrm{~mm}$ (https:// farmech.dac.gov.in/FarmerGuide/UP/ index 1.html). In the study area, equines comprise of indigenous breed of horses, donkeys and mules of all ages and sex category. Animals are maintained under traditional extensive system that does not protect them from extreme weather conditions. The available feed resources constituted natural pasture, concentrates and crop residues. They are mainly used for transport, draught and pack work type.

\section{Study design}

A cross-sectional study was conducted between August to November, 2020, for the prevalence of trypanosome infection in equines in the study area. The study animals were selected by using simple random sampling method in which expected prevalence was taken as $50 \%$ with confidence interval (CI) of 95\% (Thrusfield, 2005). A total of 285 animals comprising 220 horses and 65 donkeys/mules selected from the study area. Sampling method was based on a predesigned epidemiological questionnaire addressing the animal details like sex, age, type of work and managemental practices like helminthes infestation (Direct faecal examination method using standard procedure) to calculate the epidemiological risk factors associated with trypanosomes infection in equines in the study area. Conventional age categories were made as young $(<2$ years) and adult ( $>2$ years).

\section{Blood sample collection}

About $5 \mathrm{~mL}$ of blood from jugular vein was collected aseptically from each animal in two collecting tube. One sample was collected with EDTA for extraction of DNA for PCR amplification and hematological studies while second was collected in clot activator vials for serum collection and stored at $-20^{\circ} \mathrm{C}$ for serological examination and biochemical studies. Blood samples from animals were collected with utmost care with the prior consent of the owners.

\section{Enzyme linked immuno sorbent assay (ELISA)}

Blood samples of clot activator vials were centrifuged to generate serum and stored at $-20^{\circ} \mathrm{C}$. As a means to detect the antibodies against $T$. evansi, whole cell lysate (WCL) antigen specific indirect-ELISA was executed at National Research Center on Equines (NRCE), Hisar, Haryana, India as per the protocol standardized by Kumar et al. (2013). ELISA plates (Thermo Fisher Scientific) were coated with $50 \mu \mathrm{L}$ diluted in $0.1 \mathrm{M}$ carbonate/ bicarbonate buffer ( $\mathrm{pH}$ 9.6) containing $500 \mathrm{ng}$ WCL antigen (Kumar et al., 2013) per well. Plates were incubated overnight at $4{ }^{\circ} \mathrm{C}$ then washed six times with phosphate buffer saline containing $0.05 \%$ Tween-20 (PBS-T). ELISA 
plates were blocked with $100 \mu \mathrm{L}$ blocking buffer ( $5 \%$ skimmed milk in PBS-T) then incubated at $37^{\circ} \mathrm{C}$ for 1 hour. After washing, $50 \mu \mathrm{L}$ of 1:100 diluted field sera sample in 5\% skimmed milk in PBS-T were loaded in duplicate. The plates were incubated at $37^{\circ} \mathrm{C}$ for 1 hour and washed with PBST followed by $50 \mu \mathrm{L}$ of $1: 15,000$ dilution of anti-Horse IgG (Sigma- Aldrich) were added to the wells and again incubated for 1 hour at $37^{\circ} \mathrm{C}$. Finally, $50 \mu \mathrm{L}$ of 1:20 dilution tetra methyl benzidene substrate ((TMB, GeNei $\left.\left.{ }^{\mathrm{TM}}\right)\right)$ was added per well. The reaction was stopped by adding $50 \mu \mathrm{L}$ of $1 \mathrm{M}$ sulphuric acid. The absorbance was read at $450 \mathrm{~nm}$ on ELISA reader (Thermo Fisher Scientific, Finland) and results were expressed as mean OD 450 of duplicate samples.

\section{DNA Extraction and Polymerase chain reaction (PCR) assay \\ Genomic DNA was extracted from} whole blood samples by Phenol chloroform isoamyl alcohol (PCI) method of DNA extraction with little modification of the method used by Sambrook and Russel (2001). DNA pellet, extracted by this method, was dissolved in $30-50 \mu \mathrm{L}$ of nuclease free water (NFW) and stored at $-40^{\circ} \mathrm{C}$ for further use. Extracted DNA was checked by agarose $(0.5 \%)$ gel electrophoresis. PCR was performed using ISG-F/R (Invariable surface glycoproteinforward/reversed) primers (ISG-F $5^{1}$ AAAGCCACCGAAGATGCAGA $3^{1}$ and ISGR $5^{1}$ TTGTCCCAATCCAGCCACTC $3^{1}$ ) for amplification of $196 \mathrm{bp}$ of repetitive sequence of mini-chromosome satellite (Masiga et al., 1992; Kumar et al., 2016). The DNA template was amplified in $25 \mu \mathrm{L}$ of PCR reaction mixture using Top Taq master mix $2 x$ of Qiagen (5 unit/ $\mu \mathrm{L}$ Taq DNA polymerase, $3 \mathrm{mM} \mathrm{MgCl}_{2}$ and $400 \mu \mathrm{M}$ each dNTP), $0.4 \mu \mathrm{M}$ of each primer and $2.0 \mu \mathrm{M}$ template DNA $(>40 \mathrm{ng} / \mu \mathrm{M})$ were mixed and NFW was added to make a final volume of $25 \mu \mathrm{L}$ PCR condition was optimized with ISG primers as follows: initial denaturation for 5 minutes at $95^{\circ} \mathrm{C}$ followed by 35 cycles at $94^{\circ} \mathrm{C}$ for 30 seconds (denaturation), annealing at $58^{\circ} \mathrm{C}$ for 30 seconds and extension at $72^{\circ} \mathrm{C}$ for 30 seconds. The amplified PCR products were resolved by electrophoresis on $1.5 \%$ agarose gel and visualized under UV transilluminator mega Lum G gel imaging system (Aplegen Inc., USA) for detection of 196bp product size.

\section{Interaction with hemato-biochemical parameters \\ PCR positive blood samples (might or} might not be positive by indirect ELISA) were further analyzed for hemato-biochemical estimation with an equivalent non-infected control blood samples for comparative study. Total erythrocytes count (TEC), total leukocytes count (TLC), hemoglobin (Hb), packed cell volume (PCV), differential leucocytes count (DLC), mean corpuscular volume (MCV) and mean corpuscular hemoglobin concentration (MCHC) were estimated as described by Ghaffar et al. (2014). Different serum biochemical parameters such as total serum protein (TSP), serum albumin, serum glucose, aspartate aminotransferase (AST), alanine aminotransferase (ALT), gamma glutamyltransferase (GGT), creatinine, bilirubin total (BIT), bilirubin indirect (BID), serum cholesterol, serum urea nitrogen, uric acid (UA) were estimated using Clinical Chemistry Analyzer (ERBAEM200).

\section{Statistical analysis}

The range of molecular and serological prevalence was determined at $95 \%$ confidence interval calculated using online calculator (http:/ /www.mccallum-layton.co.uk/stats/ Confidence Interval CalcProportions.aspx), determination of epidemiological risk factors were statistically analyzed by chi-square test and data regarding hemato-biochemical parameters were done by Student's t-test, using Graphpad prism software (version 8.0.2) and the value of $p<0.05$ was considered as statistically significant.

\section{RESULTS}

\section{Molecular and serological prevalence}

The samples were considered positive only 


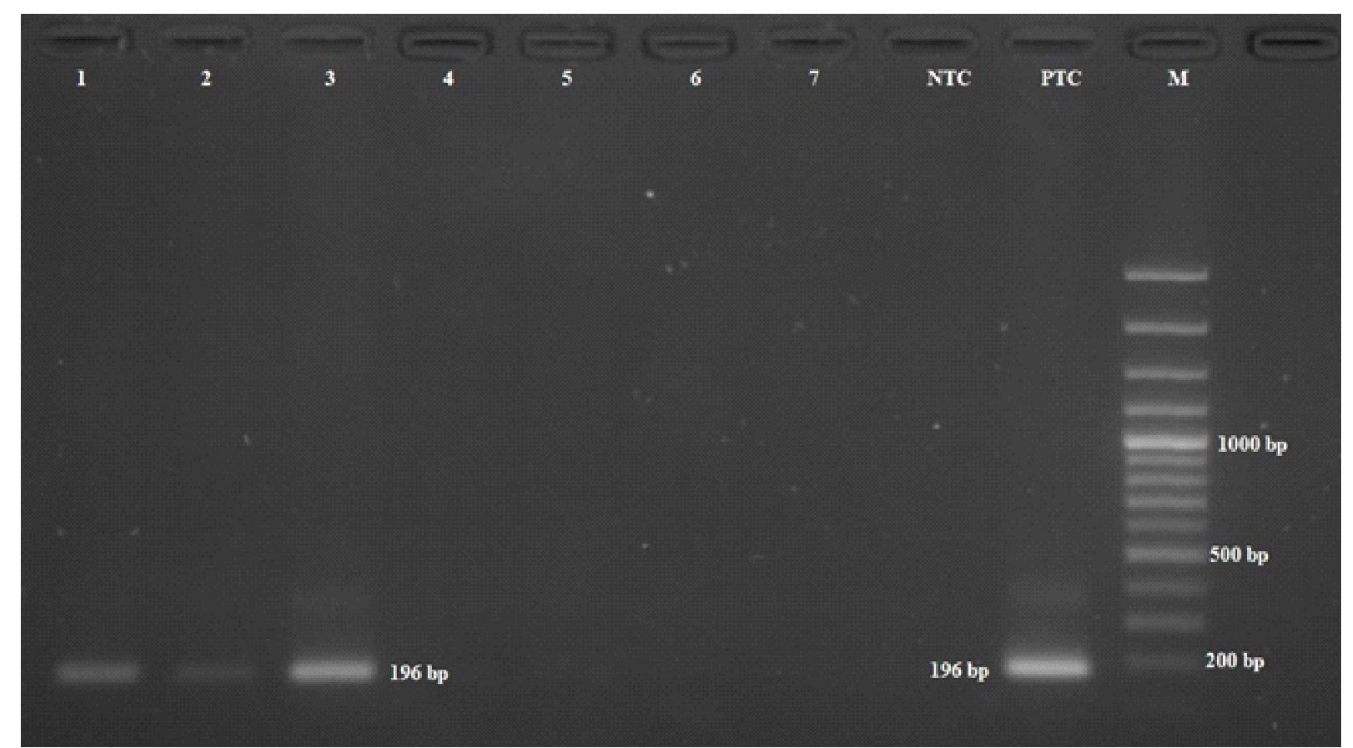

Fig. 1. Agarose gel (1.5\%) electrophoresis of 196 bp of PCR product for T. evansi. Lane 1-7: Test samples, NTC- Negative template control, PTC- Positive template control, M- 100bp plus DNA ladder

showed single band of 196 bp size (Fig. 1) on agarose gel $(1.5 \%)$ electrophoresis. The RPP (relative percent positivity) value of $15 \%$ was considered as cut-off threshold in indirect ELISA to estimate seropositivity against $T$. evansi infection (Kumar et al., 2013). Out of 285 samples examined, $43(15.08 \%$ and $95 \%$ $\mathrm{CL}=11.14-19.78)$ and $55(19.29 \%$ and $95 \%$ $\mathrm{CL}=14.88-24.37$ ) samples were found to be positive by ISG- PCR and indirect ELISA, respectively (Table 1). The seroprevalence of T. evansi ranged from $5.88 \%$ (Ambedkar Nagar district) to $51.06 \%$ recorded in Ghazipur district. The lowest or absent molecular prevalence was also observed in four districts (Sultanpur, Sant Ravidas Nagar, Pratapgarh and Ambedkar Nagar) of current study area (Table 1).

\section{Evaluation of epidemiological risk factors}

The prevalence of trypanosomes

Table 1. Prevalence of equine trypanosomosis in various districts of Eastern Plane zone, U. P.

\begin{tabular}{lccccc}
\hline \multicolumn{1}{c}{ District } & $\begin{array}{l}\text { Total } \\
\text { samples }\end{array}$ & $\begin{array}{l}\text { PCR positive } \\
\text { samples (\%) }\end{array}$ & 95\% CL & $\begin{array}{l}\text { ELISA positive } \\
\text { samples (\%) }\end{array}$ & 95\% CL \\
\hline Barabanki & 17 & $2(11.76)$ & $1.46-36.44$ & $3(17.64)$ & $3.80-43.43$ \\
Ayodhya & 44 & $4(9.09)$ & $2.53-21.67$ & $4(9.09)$ & $2.53-21.67$ \\
Sultanpur & 17 & $0(0.00)$ & $0-19.51^{*}$ & $1(5.88)$ & $0.15-28.69$ \\
Jaunpur & 19 & $2(10.52)$ & $1.30-33.14$ & $2(10.52)$ & $1.30-33.14$ \\
Azamgarh & 16 & $1(6.25)$ & $0.16-30.23$ & $2(12.50)$ & $1.55-38.35$ \\
Mau & 24 & $3(12.50)$ & $2.66-32.36$ & $4(16.66)$ & $4.74-37.38$ \\
Ballia & 21 & $5(23.80)$ & $8.22-47.17$ & $6(28.57)$ & $11.28-52.17$ \\
Ghazipur & 47 & $22(46.80)$ & $32.11-61.92$ & $24(51.06)$ & $36.06-65.92$ \\
Varanasi & 17 & $2(11.76)$ & $1.46-36.44$ & $3(17.64)$ & $3.80-43.43$ \\
Santravidasnagar & 9 & $0(0.00)$ & $0-33.63^{*}$ & $1(11.11)$ & $0.28-48.25$ \\
Pratapgarh & 15 & $0(0.00)$ & $0-21.8^{*}$ & $1(6.66)$ & $0.17-31.95$ \\
Chandauli & 22 & $2(9.09)$ & $1.12-29.16$ & $3(13.63)$ & $2.91-34.91$ \\
Ambedkarnagar & 17 & $0(0.00)$ & $0-19.51^{*}$ & $1(5.88)$ & $0.15-28.69$ \\
Total & 285 & $43(15.08)$ & $11.14-19.78$ & $55(19.29)$ & $14.88-24.37$ \\
\hline Ond & & &
\end{tabular}

One sided $97.5 \%$ confidence interval 
infection was $9.09 \%$ and $11.82 \%$ in horses whereas in donkey/ mule, it was found to be $35.38 \%$ and $44.62 \%$ by PCR and indirectELISA test, respectively (Table 2). The variation in prevalence of infection among the equine species was statistically highly significant $(\mathrm{p}<0.01)$. Donkeys/mules population was at 27.08 and 34.65 times more prone to infection as compared to the horses. But no significant difference $(\mathrm{p}<0.05)$ was observed in respect of prevalence of trypanosomosis among sex of equines (Table 2$)$. The young animals $(<2$ years) showed significantly $(\mathrm{p}<0.05)$ higher incidence (27.9\% and $32.55 \%$ ) of $T$. evansi infection than adult animals (12.80\% and $16.94 \%)$ by PCR and indirect ELISA test. They were at 2.17 and 1.10 times more risk of infection as compared to adult animals (Table 2). Helminths infested animals were observed significantly $(\mathrm{p}<0.05)$ more prone to $T$. evansi infection $(21.18 \%$ and $25.42 \%)$ than the helminths free equines $(10.77 \%$ and $14.97 \%)$ by PCR and indirect
ELISA test shown in Table 2. The equines used for bricks kiln purpose had more prevalence (20.45\% and $25.58 \%$ ) of infection than those used for other transport (16.08\% and $16.58 \%$ ) work, but this variation was not statistically significant (Table 2).

\section{Estimation of hemato-biochemical alterations}

Assessments of different hematological parameters depicted that the mean value of $\mathrm{Hb}$, $\mathrm{PCV}, \mathrm{TEC}, \mathrm{MCV}$ and $\mathrm{MCHC}$ were significantly $(\mathrm{p}<0.01)$ lower in PCR positive animals than control (Table 3). Absolute count of lymphocyte cells was decreased significantly in infected animals (Table $3)$. The value of TSP, albumin, globulin and serum glucose were recorded significantly $(\mathrm{p}<0.01)$ lower in infected equines than control (Table 3). A significantly $(\mathrm{p}<0.01)$ increased value of different serum biochemical parameters such as ALT, AST, GGT, blood urea, creatinine and uric acid was recorded in infected animals compared to infection free animals (Table 3 ).

Table 2. Equine trypanosomosis associated epidemiological risk factors diagnosed by PCR and indirect-ELISA in the study areas

\begin{tabular}{|c|c|c|c|c|c|c|c|}
\hline $\begin{array}{l}\text { Prevalence } \\
\text { test } \\
\end{array}$ & Variables & Category & $\begin{array}{l}\text { Total } \\
\text { animals } \\
\end{array}$ & $\begin{array}{l}\text { Infected } \\
\text { animals }(\%)\end{array}$ & $\chi^{2}$ & $\mathbf{R R}$ & p-value \\
\hline \multirow{10}{*}{$\begin{array}{l}\text { Diagnostic } \\
\text { Polymerase } \\
\text { chain reaction } \\
\text { (PCR) }\end{array}$} & \multirow[t]{2}{*}{ Animal } & Horse & 220 & $20(9.09)$ & \multirow[t]{2}{*}{27.08} & & \multirow[t]{2}{*}{0.0001} \\
\hline & & Donkey/ mules & 65 & $23(35.38)$ & & $3.89^{* *}$ & \\
\hline & \multirow[t]{2}{*}{ Sex } & Male & 111 & $16(14.41)$ & 0.06 & & \multirow[t]{2}{*}{0.79} \\
\hline & & Female & 174 & $27(15.52)$ & & $1.07^{\mathrm{NS}}$ & \\
\hline & \multirow[t]{2}{*}{ Age } & $<2$ years & 43 & $12(27.90)$ & 6.49 & $2.17^{*}$ & \multirow[t]{2}{*}{0.01} \\
\hline & & $>2$ years & 242 & $31(12.80)$ & & & \\
\hline & \multirow{2}{*}{$\begin{array}{l}\text { Helminthp } \\
\text { arasites }\end{array}$} & Present & 118 & $25(21.18)$ & 5.846 & $1.96^{*}$ & \multirow[t]{2}{*}{0.01} \\
\hline & & Absent & 167 & $18(10.77)$ & & & \\
\hline & \multirow[b]{2}{*}{ Work } & Brick kiln & 86 & $18(20.45)$ & 3.28 & $1.66^{\mathrm{NS}}$ & \multirow[t]{2}{*}{0.07} \\
\hline & & Transport & 199 & $25(16.08)$ & & & \\
\hline \multirow{10}{*}{$\begin{array}{l}\text { Indirect- } \\
\text { enzyme linked } \\
\text { immuno } \\
\text { sorbent assay } \\
\text { (ELISA) }\end{array}$} & \multirow[t]{2}{*}{ Animal } & Horse & 220 & $26(11.82)$ & 34.65 & & \multirow[t]{2}{*}{0.0001} \\
\hline & & Donkey/ Mule & 65 & $29(44.62)$ & & $3.77^{* *}$ & \\
\hline & \multirow[t]{2}{*}{ Sex } & Male & 111 & $18(16.22)$ & 1.10 & & \multirow[t]{2}{*}{0.29} \\
\hline & & Female & 174 & $37(21.26)$ & & $1.31^{\mathrm{NS}}$ & \\
\hline & \multirow[t]{2}{*}{ Age } & $<2$ years & 43 & $14(32.55)$ & 5.71 & $1.10^{*}$ & \multirow[t]{2}{*}{0.016} \\
\hline & & $>2$ years & 242 & $41(16.94)$ & & & \\
\hline & \multirow{2}{*}{$\begin{array}{l}\text { Helminth } \\
\text { parasites }\end{array}$} & Present & 118 & $30(25.42)$ & 4.85 & $1.69^{*}$ & \multirow[t]{2}{*}{0.02} \\
\hline & & Absent & 167 & $25(14.97)$ & & & \\
\hline & \multirow[b]{2}{*}{ Work } & Brick kiln & 86 & $22(25.58)$ & 3.12 & & \multirow[t]{2}{*}{0.07} \\
\hline & & Transport & 199 & $33(16.58)$ & & & \\
\hline
\end{tabular}

$\chi 2=$ Chi square, $\mathrm{RR}=$ relative risk, NS-non significant $(\mathrm{P}>0.05),{ }^{*}$ significant $(\mathrm{P}<0.05), * *$ highly significant $(\mathrm{P}<0.01)$ 
Table 3. Hemato-biochemical parameters of $T$. evansi infected and non-infected equines

\begin{tabular}{|c|c|c|c|c|}
\hline Parameters & Control & Infected animals & t- test & $P$ value \\
\hline Hemoglobin (g \%) & $10.53 \pm 0.28$ & $4.76 \pm 0.17$ & $17.36^{* *}$ & 0.0001 \\
\hline Haematocrit (\%) & $34.16 \pm 0.61$ & $20.00 \pm 0.62$ & $16.14^{* *}$ & 0.0001 \\
\hline TEC $\left(\mathrm{x} 10^{3}\right.$ cells $\left./ \mu \mathrm{L}\right)$ & $7.44 \pm 0.45$ & $2.65 \pm 0.17$ & $9.88^{* *}$ & 0.0001 \\
\hline MCV (fl) & $47.88 \pm 3.04$ & $79.66 \pm 6.4$ & $4.47^{* *}$ & 0.0001 \\
\hline $\mathrm{MCHC}(\mathrm{g} / \mathrm{dL})$ & $30.87 \pm 0.85$ & $24.03 \pm 1.04$ & $5.08^{* *}$ & 0.0001 \\
\hline TLC $\left(\mathrm{x} 10^{3}\right.$ cells $\left./ \mu \mathrm{L}\right)$ & $8.07 \pm 0.37$ & $7.52 \pm 0.40$ & $0.95^{\mathrm{NS}}$ & 0.1739 \\
\hline Lymphocyte $\left(\times 10^{3}\right.$ cells $\left./ \mu \mathrm{L}\right)$ & $3.90 \pm 0.21$ & $2.82 \pm 0.20$ & $3.70^{* *}$ & 0.0006 \\
\hline Neutrophil (x10³ cells/ $\mu \mathrm{L})$ & $3.47 \pm 0.19$ & $3.85 \pm 0.28$ & $1.11^{\mathrm{NS}}$ & 0.1380 \\
\hline Monocyte $\left(\mathrm{x} 10^{3}\right.$ cells $\left./ \mu \mathrm{L}\right)$ & $0.25 \pm 0.01$ & $0.31 \pm 0.02$ & $1.59^{\mathrm{NS}}$ & 0.0628 \\
\hline Eosinophil $\left(\mathrm{x} 10^{3}\right.$ cells $\left./ \mu \mathrm{L}\right)$ & $0.32 \pm 0.02$ & $0.39 \pm 0.04$ & $1.31^{\mathrm{NS}}$ & 0.1019 \\
\hline Basophil $\left(\mathrm{x} 10^{3}\right.$ cells $\left./ \mu \mathrm{L}\right)$ & $0.12 \pm 0.01$ & $0.15 \pm 0.01$ & $1.24^{\mathrm{N} \mathrm{S}}$ & 0.1130 \\
\hline TSP $(g / d L)$ & $5.83 \pm 0.12$ & $2.08 \pm 0.41$ & $8.71^{* *}$ & 0.0001 \\
\hline Albumin $(\mathrm{g} / \mathrm{dL})$ & $2.57 \pm 0.07$ & $0.73 \pm 0.12$ & $12.64^{* *}$ & 0.0001 \\
\hline Globulin (g/dL) & $3.26 \pm 0.15$ & $1.35 \pm 0.30$ & $5.62^{* *}$ & 0.0001 \\
\hline Glusoce (mg/dL) & $69.76 \pm 1.61$ & $27.69 \pm 1.20$ & $20.91^{* *}$ & 0.0001 \\
\hline ALT (U/L) & $34.21 \pm 1.12$ & $69.88 \pm 3.46$ & $9.79^{* *}$ & 0.0001 \\
\hline AST (U/L) & $167.69 \pm 5.30$ & $210.00 \pm 12.49$ & $3.11^{* *}$ & 0.0025 \\
\hline GGT (U/L) & $21.93 \pm 2.50$ & $34.64 \pm 1.04$ & $4.68^{* *}$ & 0.0001 \\
\hline Blood urea $(\mathrm{mg} / \mathrm{dL})$ & $19.50 \pm 1.48$ & $38.55 \pm 6.11$ & $3.03^{*}$ & 0.0031 \\
\hline Creatinine (mg/dL) & $1.37 \pm 0.08$ & $1.97 \pm 0.09$ & $4.59^{* *}$ & 0.0001 \\
\hline Uric (mg/dL) & $0.33 \pm 0.02$ & $0.69 \pm 0.00$ & $3.62^{* *}$ & 0.0008 \\
\hline $\mathrm{BID}(\mathrm{mg} / \mathrm{dL})$ & $0.23 \pm 0.01$ & $0.17 \pm 0.07$ & $0.79^{\mathrm{NS}}$ & 0.2166 \\
\hline BIT (mg/dL) & $0.470 \pm 0.05$ & $1.00 \pm 0.22$ & $1.26^{\mathrm{NS}}$ & 0.1104 \\
\hline Triglycerides $(\mathrm{mg} / \mathrm{dL})$ & $17.00 \pm 2.21$ & $19.33 \pm 3.09$ & $0.61^{\mathrm{NS}}$ & 0.2731 \\
\hline Cholesterol $(\mathrm{mg} / \mathrm{dL})$ & $80.33 \pm 2.98$ & $78.66 \pm 3.08$ & $0.38^{\mathrm{NS}}$ & 0.3507 \\
\hline
\end{tabular}

NS- non significant $(\mathrm{P}>0.05), *$ significant $(\mathrm{P}<0.05), * *$ highly significant $(\mathrm{P}<0.01)$

\section{DISCUSSION}

The current study demonstrated the prevalence of $T$. evansi infection in equines diagnosed by ISG-PCR and indirect-ELISA method and also the epidemiological risk factors along with hemato-biochemical alteration associated with equine trypanosomosis in the study area. The overall prevalence of $T$. evansi infection in equines was observed $15.08 \%$ and $19.29 \%$ by molecular and serological methods, respectively. The present seroprevalence data corroborates well with the findings of Kumar et al. (2013) who reported 19.69\% seroprevalence of $T$. evansi in equines of Uttar Pradesh state, India.
A strong correlation was also observed between equine trypanosomosis and environmental as well as epidemiological risk factors in exposed animals in the study area. Prevalence of trypanosomosis was increased significantly $(\mathrm{p}<0.01)$ in donkeys/mules population than the horses. Similar finding was also observed by Camoin et al. (2019) and Kouam et al. (2010). Comparatively higher risk of trypanosomosis in donkeys/ mules might be due to traditional extensive rearing system with poor management practices and used for haulage and transport for which they are more exposed to flies than horses. Occurrence of trypanosomosis showed no statistically 
significant difference among sex of equines. This finding is in line with the earlier investigations (Bekele and Nasir, 2011; Tafese et al., 2012; Sumbria et al., 2014). This might be due to an equal chance of exposure to the infection and similar distribution of parasite between the sexes. The young animals showed significantly $(\mathrm{p}<0.05)$ higher prevalence of T. evansi infection means they had at 2.17 and 1.10 times more risk of infection as compared to adult animals. Similar findings have been reported by Abebayehu et al. (2011) in animal trypanosomosis. Sumbria et al. (2014) reported that young equines were supposed to be thrice at the chance of $T$. evansi infection as compared to the adults. This could be due to the fact that young animals do not have strong immune responses against trypanosomes infection and therefore they are not able to control the parasitemia during infection. Helminths infested animals had 1.96 and 1.69 times more risk of infection as compared to non-infested animals. This result is in line with the earlier work (Sumbria et al., 2014). This could be due to poor management and open housing system where wasted feed and their manure would not be cleaned regularly. Thus, the chance of infection was high due to more exposure to insect or flies as compared to helminths free equines. The equines used for bricks transport especially donkeys were seen at high risk of infection. This record is in agreement with previous workers (Burn et al., 2010). The current study suggested that the animals used in bricks transport were more likely to have skin injury, soil surface abnormalities and more risk of ectoparasite or fly infestation than those equines used for other transport purposes.

In the present study, PCR positive samples were used for hemato-biological estimation against the non infected control because PCR is a very high sensitive and enough to detect the early stage of active T. evansi infection (Rudramurthy et al., 2013). Indirect ELISA is not sensitive to detect the early stage of infection. Moreover, in treated cases, also the anti-trypanosomal antibodies persisted over 6 months or even more (Monzon et al., 2003; Yadav et al., 2012). A significantly devaluation of blood cellular variable noticed in $T$. evansi infected animals suggested that lyses of erythrocytes due to RBC destruction by the flagellar movement of trypanosomes, indiscriminate phagocytosis by activated macrophage, hemolysis of RBCs by hemolysin released by parasites and non compensatory erythropoiesis (Bal et al., 2014). Previous workers were also noticed lymphopenia in animals infected with trypanosomosis (Abubakar et al., 2005). Lymphopenia could be a result of immuno-suppression due to shrunken of lymphoid organs (Abubakar et al., 2005). Abo-Aziza et al. (2017) and Hota et al. (2019) have also been reported lower level of TSP, albumin, globulin and serum glucose in the animal infected with surra. The hypoalbuminaemia might be occurred due to uptake of albumin bound fatty acid and lipoproteins, while hypoglobulinaemia due to increased hepatocellular damage take place during the infection of trypanosomosis (Mishra et al., 2017; Hota et al., 2019). Previous investigators have been also reported hypoglycemia in trypanosomosis (Habila et al., 2012) and it has been suggested that it might be due to rapid consumption of the blood glucose by trypanosomes for their metabolism during infection (Bal et al., 2014) and also the increased metabolic rate of host during fever as well as hepatocyte degeneration (Garba and Mayaki, 2018). Elevation of ALT and AST enzymes could be due to increased levels of systemic antigen-antibody immune complexes and their consequent accumulation in the vital organs. This might play a role of tissue breakdown and inflammation in the host body (Sivajothi et al., 2015). Centrilobular degeneration consequences hypoxia and severe oxidative stress induced by $T$. evansi infection (Abd El-Baky and Salem, 2011). The level of GGT recorded significantly $(\mathrm{p}<0.05)$ higher is suggestive of tissue breakdown and inflammation in the animal's body or might be due to lysed trypanosomes at different stages 
of the infection (Parashar et al., 2018). The level of blood urea, creatinine and uric acid observed significantly $(p<0.05)$ higher in $P C R$ positive animals might be due to acidosis or primary renal insufficiency caused by decreased renal blood flow (Seleim, 2003). All other hematobiochemical variables in infected animals were not statistically significant from non-infected equines.

The present study revealed that $15.08 \%$ of equines were positive for trypanosomosis by diagnostic PCR and around $19.29 \%$ by in direct-ELISA that indicates subclinical trypanosomosis which is constantly prevalent in equine population and affect small number of animals on post monsoon season in the study area. Evaluation of relative risk factors with respect to molecular and serological diagnostic methods suggested that donkeys/ mules were at more risk of trypanosomes infection than horses. The young animals and helminth-

\section{REFERENCES}

Abd El-BakyAA and Salem SI, 2011. Clinicopathological and cytological studies on naturally infected camels and experimentally infected rats with Trypanosoma evansi. World Appl Sci J, 14(1): 42-50

Abebayehu T, Eset H, Berhanu M, Rahmeto A and Solomon M, 2011. Mechanically transmitted bovine trypanosomosis in Tselemty Wereda, Western Tigray, Northern Ethiopia Agric J, 6 (1): 10-13, doi: 10.3923/aj.2011.10.13

Abo-Aziza FAM, Ashry HM and Nassar SA, 2017. Haematological and biochemical alterations in sub clinically affected dromedary camels with Trypanosoma evansi. J Chem Pharm Sci, 10 (3): 1326-1334

AbubakarA, Iliyasu B, Yusuf AB, Igweh AC, Onyekwelu NA et al., 2005. Antitrypanosomal and haematological effects of selected Nigerian medicinal plants in Wistar rats. Biokemistri, 17(2): 95-99, doi: 10.4314/BIOKEM.V17I2. 32593

Ahmed A, 2008. Epidemiological studies (parasitological, serological and molecular techniques) of $T$. evansi infection in camels in Egypt. Vet World, 1(11): 325-328, doi: 10.5455/ vetworld.2008.325-328 infested animals were also more susceptible to this infection. Finally, significant changes in hemato-biochemical parameters in subclinically infected animals could be helpful in the diagnosis of $T$. evansi in equines. Therefore, more surveys on equine trypanosomosis should be designed and implemented in different seasons and rest of the agro-climatic zones of eastern part of Uttar Pradesh in future.

Conflict of interest: Authors have no conflict of interest in this study.

\section{ACKNOWLEDGEMENTS}

Thanks to the Vice-chancellor of ANDUAT, Kumarganj, Ayodhya for providing facilities to do the present work. We would like to thank to the field veterinarians of the study area, members of Parasitology Laboratory, National Research Center on Equines (NRCE), Hisar, Haryana for their contribution and support.

Aregawi WG, Agga GE, Abdi RD and Buscher P, 2019. Systematic review and meta-analysis on the global distribution, host range, and prevalence of Trypanosoma evansi. Parasites Vectors, 12(1): Article 67, doi: 10.1186/s13071019-3311-4

Bal MS, Sharma A, Ashuma, Batth BK, Kaur P et al., 2014. Detection and management of latent infection of Trypanosoma evansi in a cattle herd. Indian J Anim Res. 48(1): 31-37, doi: 10.5958/ j.0976-0555.48.1.007

Bekele M and Nasir M, 2011. Prevalence and host related risk factors of bovine trypanosomosis in Hawagelan district, West Wellegazone, Western Ethiopia. Afr J Agr Res, 6(22): 5055-5060

Burn CC, Dennison TL and Whay HR, 2010. Environmental and demographic risk factors for poor welfare in working horses, donkeys and mules in developing countries. Vet J, 186(3): 385-392, doi: 10.1016/j.tvj1.2009.09.016

Camoin M, Kocher A, Chalermwong P, Yangtarra S, Kamyingkird K et al., 2019. The indirect ELISA Trypanosoma evansi in equids: optimisation and application to a serological survey including racing horses, in Thailand. Bio Med Res Int, 2019: 1-12, doi:10.1155/2019/2964639 
Prevalence and relative risk factors associated with equine trypanosomosis

Garba UM and Mayaki AM, 2018. Fluctuations in blood glucose level of donkeys infected with Trypanosoma evansi. ARC J Anim Vet Sci, 4(1): 14-21, doi: 10.20431/2455-2518.0401003

Ghaffar A, Ashraf S, Hussain R, Hussain T, Shafique M et al., 2014. Clinicohematological disparities induced by triazophos (organophosphate) in Japanese quail. Pakistan Vet J, 34(2): 257-259

Habila N, Inuwa MH, Aimola IA, Udeh MU and Haruna E, 2012. Pathogenic mechanisms of Trypanosoma evansi infection. Res Vet Sci, 93(1): 13-17, doi: 10.1016/j.rvsc.2011.08.011

Hota A, Maiti SK and Ghosh RC, 2019. Therapeutic efficacy of quinapyramine compounds in T. evansi affected cattle. Pharma Innovation, 8 (9): 467-471

Kouam MK, Kantzoura V, Gajadhar AA, Theis JH, Papadopoulos E et al., 2010. Seroprevalence of equine piroplasms and host-related factors associated with infection in Greece. Vet Parasitol, 169(3-4): 273-278, doi: 10.1016/j.vetpar. 2010.01.011

Kumar R, Gaur DK, Goyal SK, Sharma P, kankar SK et al., 2016. Sensitive detection of Trypanosome evansi infection by polymerase chain reaction targeting invariable surface glycoprotein gene. Indian J Anim Sci, 86(6): 639-642

Kumar R, Kumar S, Khurana SK and Yadav SC, 2013. Development of an antibody ELISA for seroprevalence of Trypanosoma evansi in equids of North and North-western regions of India. Vet Parasitol, 196(3-4): 251-257, doi: 10.1016/ j.vetpar.2013.04.018

Kumar R, Shikha J, Kumar S, Sethi K, Kumar S et al., 2017. Impact estimation of animal trypanosomosis (surra) on livestock productivity in India using simulation model: current and future perspective. Vet Parasitol, 10: 1-12, doi: 10.1016/j.vprsr.2017.06.008

Masiga DK, Smyth AJ, Hayes P, Bromidge TJ and Gibson WC, 1992. Sensitive detection of trypanosomes in Tsetse flies by DNA amplification. Int J Parasitol, 22(7): 909-918, doi: 10.1016/0020-7519(92)90047-O

Mishra RR, Senapati SK, Sahoo SC, Das MR, Sahoo G et al., 2017. Trypanosomiasis induced oxidative stress and hemato-biochemical alteration in cattle. J Entomol Zool Stud, 5(6): 721-727

Monzon CM, Mancebo OA and Russo AM, 2003. Antibody level by indirect ELISA test in
Trypanosoma evansi infected horse following treatment with quinqpyramine sulphate. Vet Parasitol, 111(1): 59-63, doi: 10.1016/S03044017(02)00331-X

Parashar R, Singla LD, Gupta M and Sharma SK, 2018. Evaluation and correlation of oxidative stress and haemato-biochemical observations in horses with natural patent and latent trypanosomosis in Punjab state of India. Acta Parasitol, 63(4): 733-743, doi:10.1515/ap-20180087

Rudramurthy GR, Sengupta PP, Balamurugan V, Prabhudas K and Rahman H, 2013. PCR based diagnosis of trypanosomiasis exploring invariant surface glycoprotein (ISG) 75 gene. Vet Parasitol, 193(1-3): 47-58, doi: 10.1016/ j.vetpar.2012.11.045

Sambrook J and Russell DW, 2001. Molecular CloningA Laboratory Manual. $3^{\text {rd }}$ edn., pp 1.1-7.94, https://www.sigmaaldrich.com/IN/en/product/ sigma/m8265

Seleim RS, Tos A, Mohamed SR, Nada HS and Gobran RA, 2003. ELISA and other tests in the diagnosis of Pasteurella multocida infection in camels. Proceedings of the International Conference on Agriculture Research for Development, Oct 8-10 Sivajothi S, Rayulu VC and Reddy BS, 2015. Haematological and biochemical changes in experimental Trypanosoma evansi infection in rabbits. J Parasit Dis, 39(2): 216-220, doi: 10.1007/s12639-013-0321-6

Sumbria D, Singla LD, Sharma A, Moudgil AD and Bal MS, 2014. Equine trypanosomosis in central and western Punjab: prevalence, haematobiochemical response and associated risk factors. Acta trop, 138: 44-50, doi: 10.1016/ j.actatropica.2014.06.003

Tafese W, Melaku A and Fentahun T, 2012. Prevalence of bovine trypanosomosis and its vectors in two districts of East Wollega zone, Ethiopia. Onderstepoort J Vet Res, 79(1): 123- 128, doi: 10.4102/ojvr.v79i1.385

Thrusfield M, 2005. Veterinary Epidemiology, $2^{\text {nd }}$ edn., Blackwell Science Ltd., UK

Yadav SC, Kumar R, Manuja A, Goyal L and Gupta AK, 2012. Early detection of Trypanosoma evansi infection and monitoring of antibody levels by ELISA following treatment. J Parasit Dis, 38: 124-127, doi: 10.1007/s12639-012-0204-2

Received 30.03.2021, Accepted -13.05.2021, Published - 01.06.2021

Section Editor: Prof. S. N. Joardar, Associate Editor 